\title{
Gláz Edit professzor asszony 90 éves!
}

A Semmelweis Egyetem, II. Belgyógyászati Klinika Endokrin Munkacsoportja és az endokrinológiával foglalkozó szakmai közösség örömmel köszönti professzor asszonyt 90. születésnapja alkalmából.

Dr. Gláz Edit egyetemi tanár, az orvostudományok doktora ez évben 90 éves. 90 év az három emberöltő! Kimondani sok, de olyan tartalommal megtölteni, ahogyan azt Gláz Edit tette, az csodálnivaló, szinte hihetetlen, de - szerencsére - mégis igaz.

A professzor asszony - ahogyan munkatársai, kollégái és egyben tanítványai gondolnak rá - életét a munka töltötte és tölti ki. Orvosi hivatásának kezdete a legendás Gömöri-klinikához kötődik, és mindvégig ez a klinika a helyszíne sok-sok évtizedes munkájának.

Személyében csodálatosan egyesíti az egyetem hármas feladatát: gyógyítás, oktatás, kutatás. E hármas feladat közül egyiket sem lehet a többi elé tenni, mindháromban maradandót alkotott. Betegeiért minden lehetségest és sokszor szinte lehetetlent is megtett, szakmai tudásával csak hivatástudata vetekedhet. Klinikai munkájának kezdete kora reggel, a vége pedig az éjszakába nyúlt. A hazai endokrinológia fejlődése - Julesz Miklós profeszszor mellett - az ő nevéhez füződik, és ez irányú szakmai hírneve világszerte ismert és elismert.

Előadóként szinte az egész világot bejárta, viszont az is igaz, hogy a kongresszusoknak helyet adó városokban csak a szállodákat és a kongresszusi előadótermeket ismerte meg. Az előbbiekben keveset, az utóbbiakban annál többet tartózkodott. Közeli munkatársai tudják leginkább, hogy előadásai között nem tett különbséget: a nemzetközi szereplésre és az orvostanhallgatóknak tartott előadásra egyforma lelkiismeretes munkával készült fel.

Felsorolni nem, csak említeni tudjuk, hogy több - hazai és idegen nyelven megjelent - könyvnek, sok száz tudományos közleménynek a szerzője.

Ha valami mégis kiemelhetô munkásságából: tanítványainak nagy száma, akik az ő szerető - és szigorú - irányításával a hazai endokrinológiai közéletben megérdemelten magas beosztásban és színvonalon képviselték és képviselik a „Gláz-iskolát”.
Idézek egy tanítványa könyvének utószavából, amely jó összefoglalója Gláz professzor asszony életfelfogáá́nak: „Az orvosi munkában a vereség elfogadhatatlan. $\mathrm{Ha}$ az értelem meg is magyarázza, az érzelem nem adhat felmentést. Aki az orvosi mesterségnek szenteli életét, számítson arra, hogy egy élet kell a tanuláshoz. Az ön-

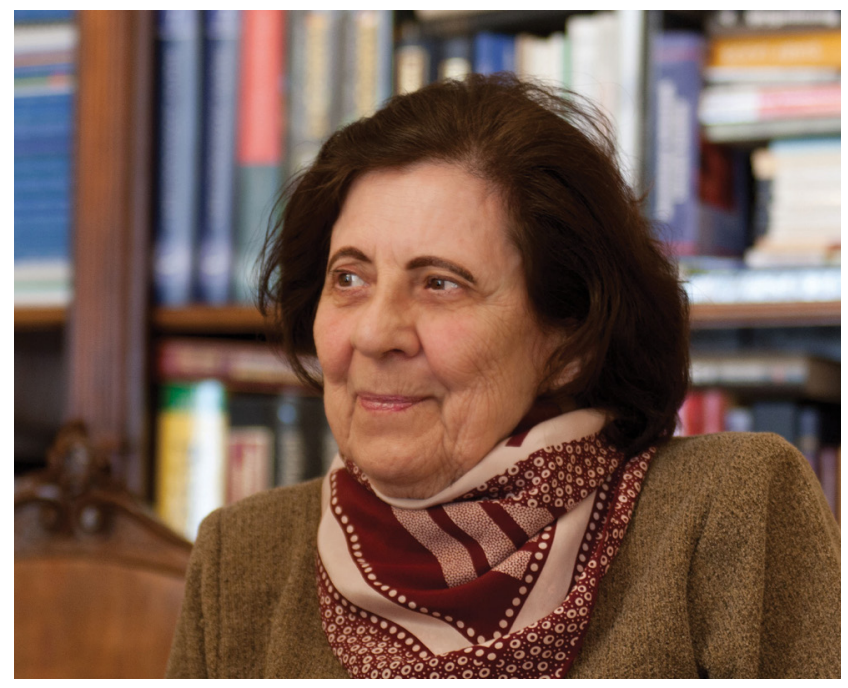

képzést abbahagyni lehet, de befejezni nem! Mindezt az igazságot volt kitől megtanulnom: Gláz Edittől, aki medikusként gyakorlatvezetóm, orvosként oktatóm és főnököm, egész életemben példaképem volt és marad. Ő nemcsak az endokrinológia szeretetét, hanem a tudomány iránti alázatot, a betegek felé megnyilvánuló hallatlan lelkiismeretességet és segíteni akarást igyekezett mindig belém plántálni."

Magas kora okozta mozgáskorlátozottsága a rendszeres munkában már akadályozza, de kívánjuk és reméljük, hogy még sokáig marad közöttünk, és erősíti bennünk a benne magas fokon meglévő hivatástudatot és elhivatottságot.

Kiss Róbert dr., tudományos fómunkatárs,

Semmelweis Egyetem, II. Belgyógyászati Klinika 